paucity of our resources. Volume 20 is essential reading for all with a serious interest in the future of non-human species.

The two other books are directed more to the popular market. Both will do much to stimulate interest in zoos, correct many misconceptions, and further understanding of the zoos' role.

Much of Elspeth Huxley's Whipsnade is given over to discussion of conservation in zoos and in the wild, in a by no means uncritical fashion. She is concerned with the problems of reintroduction and the dangers of genetic change in species held in captivity for many generations. I think she overstresses the problems in both these areas, for, given suitable protection, space and resources, a great many species can be successfully reintroduced. Genetic change has already been guarded against by professional zoo keepers, but again, resources are a problem, as she acknowledges in the last paragraph where she refers to the last animals of now extinct species which died in zoos, and the number of first-time captive breedings in British collections.

Gordon Woodroffe attempts to deal not only with conservation in the modern zoo, but also with the history both of zoos and of the many mainly mammal species both in the wild and in zoos. He has allowed too many errors to slip into print, some, I suspect, because sections were written some time ago. He gives the present Przewalski horse numbers in captivity as 250 in 52 collections, whereas according to the Studbook issued on 1 January 1981, there were 399 horses in 74 collections. He recognises only seven subspecies of tiger, missing out the Panthera tigris corbetti, and calls the Australian Taronga Park Zoo 'Tarragona'. Nevertheless, for the general reader this is a very readable book. He makes a strong plea for adequate support of the good zoos and control of those that fail to live up to the standards he rightly demands.

J.M. KNOWLES

\title{
American Wildlife Law, by Thomas A. Lund. California UP, £7.75.
}

A Londoner is reported to have described a wilderness as 'a large damp place where wild birds fly about - uncooked'. One of the virtues of Thomas Lund's study is its recognition that such pragmatic motives have helped to protect the same wildlife that is savoured. This in turn requires those with aesthetic, ethical and ecological interests in wildlife to make a deferential nod towards the accomplishments of the hunting fraternity. The author closes with a plea for 'cheerful cooperation' between these two principal protagonists of wildlife policy to stave off the new antagonist, economic development.

His entertaining description of each English wildlife law will be an eye-opener for the many who believe ecological concerns sprang forth full-grown during the last few decades. Of particular interest was the difficulty of transplanting English solutions to the barbaric American setting. The Americans were forced to abandon as aristocratic and undemocratic the most effective regulatory technique (the qualification system which limited take to people of wealth and position), while at the same time the country lacked a popular consensus that game laws deserved to be enforced. The result was the decimation of what had appeared to be an endless bounty of game before the ingenious US alternative to limit take, the prohibition of commercial hunting, was devised.

The problems of the early American system provide insight to those concerned today with conservation in other developing countries. The lesson is that, whatever our personal orientation, we cannot afford to overlook any of the multiple goals of Wildlife law identified by Lund: sustained harvest, weapons control, class discrimination or wildlife rights; nor can we be overly cavalier about the impact which different social settings can have on what are elsewhere successful solutions to wildlife conservation.

This study is full of humorous anecdotes and, as a result of the obsession of lawyers for footnotes, of obscure leads worthy of further investigation. It provides an interesting companion piece to Michael Bean's definitive Evolution of Natural Wildlife $L a w$, which is indispensable for any conservation practitioner.

R. MICHAEL WRIGHT 